\section{ECONOMICS}

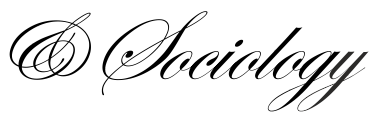

Sułkowski, L. (2019). On bullshit management - the critical management studies perspective. Economics and Sociology, 12(1), 302-312. doi: 10.14254/2071-

789X.2019/12-1/18

\title{
ON BULLSHIT MANAGEMENT - THE CRITICAL MANAGEMENT STUDIES PERSPECTIVE
}

\author{
Lukasz Sułkowski, \\ Jagiellonian University \\ E-mail: \\ lukasz:sulkowski@uj.edu.pl \\ ORCID 0000-0002-1248-2743
}

Received: November, 2018

1st Revision: January, 2019

Accepted: March, 2019

DOI: $10.14254 / 2071-$

789X.2019/12-1/18

JEL Classification: M10, M21
ABSTRACT. Harry Frankfurt established the discourse about "bullshit" in social sciences. However, in business and economics the concept is not that widely used. The purpose of this study is to explain the concept of "bullshit management". The method of research is qualitative, systematic literature review which includes bibliographical data from the Internet databases. The results leads us to two main meanings of "bullshit management". The first one is "humbug" language in business practice and the second is pseudo-scientific discourse in management theory. CMS could be the theoretical background for "bullshit management" thinking. In conclusion we underline that the critical approach to "bullshit management" could play the Ockham's razor role.

Keywords: bullshit management, critical management studies.

\section{Introduction}

The term 'bullshit' is a profane word, and first entered the language of social sciences thanks to Princeton philosopher Harry Frankfurt. Frankfurt wrote papers on the subject, and also a book entitled On Bullshit, analysing the meaning and growing social impact of this type of rhetoric and social action. According to Frankfurt, 'bullshit' is a stronger expression of 'humbug', which he describes in his book as "deceptive misrepresentation, short of lying, especially by pretentious word or deed, of somebody's own thoughts, feelings, or attitudes" (Frankfurt, 2005; Black, 1982). In this paper, the word 'bullshit' will be abbreviated to 'BS', and the phrase 'bullshit management' to 'BSM'. The main objective of the paper is to describe BSM from the perspective of Critical Management Studies. The concept of BSM might be a critical edge aimed at the instrumental nonsense rampant within the theory and practice of contemporary management.

In this age of fake news spread through social media, the issue of 'BS' is becoming more and more relevant (Ball, 2017; Pennycook \& Rand, 2018). Rapidly spreading 'infective narratives' colonise the communications space, based on crowdsourcing. These social activities frequently lack the characteristics of the 'wisdom of the crowd', instead having those of the 'stupidity of the crowd', which emerges within temporary and shallow wideranging communications processes (Lenart-Gansiniec \& Sułkowski, 2018). BSM develops 
along with social media, technology and online communication, and is used for various purposes, including political ones. For example, production and spreading of post-truths and fake news can influence people's electoral decisions and public policies (Ball, 2017; Sismondo, 2018; Belfiore, 2009). It can take the form of 'BS marketing', which means wielding influence on consumers' purchase decisions. BSM is the development and dissemination of traditional 'bullshit'. BS is mostly promoted via social media, which has a very wide range of manifestations. It is also more and more frequently serving as an instrument for achieving one's aims, which is when it becomes BSM.

\section{Literature review}

In attempting to specify what BS means, H. Frankfurt references lexicological sources and lists a few characteristics. The Oxford English Dictionary suggested the following definition: "trivial, insincere, or untruthful talk or writing; nonsense" (Frankfurt, 2005). The definition provided by the Cambridge Dictionary is "to try to persuade someone or make them admire you by saying things that are not true", with synonyms including "cheating", "tricking", "bluff" and "fleece" (https://dictionary.cambridge.org/dictionary/english/bullshit). Thus, understanding of the term clearly evolves towards manipulation and intentional disinformation by providing unverified or nonsensical information. BS is a method of communication and social action with several of its own characteristics. First of all, it is a deceptive misrepresentation - or deliberate misrepresentation - of reality. Second of all, it is different from lying because the essence of BS is not that it is false, but that it is not genuine. Third of all, BS is particularly expressed through pretentious words and deeds. Finally, it is a misrepresentation of somebody's own thoughts, feelings, or attitudes, because it gives its audience a false impression of what is going on in the mind of the speaker (Frankfurt, 2005).

G. A. Cohen distinguished different ways of understanding BS. H. Frankfurt focuses on the more colloquial and processual understanding of BS as 'BS production', meaning 'bullshitting' by the subject, i.e. the 'BS Artist'. The essence of this definition is indifference to the truth. G. A. Cohen sets BS within the academic discourse by indicating that it constitutes 'unclarifiable unclarity', and within this meaning it can be an effect of academic work (Cohen, 2002). Examples of this given by Cohen include the well-known intellectual provocation of A. Sokal published in Social Text (Sokal, 1996; Sokal \& Bricmont, 1998), and works on Marxism (Cohen, 2002).

Where do the increasing amounts of BS come from today? H. Frankfurt claimed that BS is unavoidable whenever circumstances require someone to talk without knowing what they're talking about. Politicians, businessmen, PR specialists and consultants, forced to talk about any topic, can produce BS. 'Anti-realist' doctrines undermine confidence in the value of disinterested efforts to determine what is true and what is false (Frankfurt, 2005). This is what happens in the case of extreme cognitive relativism, such as radical post-modernism, but also in the case of some social and humanist sciences, the theories of which are very difficult to falsify. These sciences include pragmatic sciences, such as business and management, as well as the sciences of education, safety and many others (Smagorinsky et al., 2010; Eubanks $\&$ Schaeffer 2008). Today, this catalogue of reasons for the popularisation of BS also includes the susceptibility of online society to manipulation by social media. This is a consequence of the ease with which fake news and post-facts are produced, the deluge of information, and the pace at which news spreads on the Internet.

Thus, considering the multiple meanings of the term BS, it is worth analysing the possibility of referencing it in contemporary management discourse. Why does this seem important? For a number of reasons. The theoretical and practical discourse of the so-called management sciences deal with infinite BS, or growing waves of BS. There is no doubt that 
both ways of understanding BS are attractive to management, in both cognitive and pragmatic reasons.

Today, BS is more and more frequently transformed into BS Management (BSM), becoming a regularly employed method of manipulation. BS becomes BSM when, following H. Frankfurt's definition, it "involves a programme of producing bullshit to whatever extent the circumstances require" (Frankfurt, 2005). In business and in the discourse of the management sciences, this is the very transformation of one-time bullshitting excesses, into regular BSM. The idea of management being scientific nonsense (the understanding of BS proposed by Cohen), is produced and promoted for the benefit of their producers (the understanding of BS proposed by Frankfurt). It is worth emphasising that the most significant characteristics of BS, as defined by Frankfurt and Cohen, are preserved. BS produced through management is nonsense. The bullshitter fakes things, but this does not necessarily mean that he gets them wrong. "The fact about himself that the bullshitter hides, on the other hand, is that the truth-values of his statements are of no central interest to him. It is impossible for someone to lie unless he thinks he knows the truth. Producing bullshit requires no such conviction." (Frankfurt, 2005).

\section{CMS and BS}

BS can also be analysed from the perspective of the development of Critical Management Studies. CMS forms a relatively new perspective, which only crystallised at the beginning of the 1990s - 1992 is considered the beginning of the institutional development of CMS, as this was when the work of M. Alvesson and H. Willmott Critical Management Studies (Alvesson \& Willmott, 1992) was published. Pioneering works in ideological demystification and managerial functions based on the structures of dominance first appeared in the 1970s (Braverman, 1974). However, it was only in the 1990s that Critical Management Studies (CMS) took the form of institutionalised discourse, thanks to the number of publications, research projects, conferences, journals and associations (e.g. the CMS Division of the American Academy of Management), (Alvesson \& Willmott, 1992).

A reconstruction of the most important assumptions of the critical current allows one to find a few of the common assumptions that make up the internally diverse paradigm of Critical Management Studies (Sułkowski, 2013; Sułkowski, 2010). This is mostly treating management sciences as a persuasive discourse stemming from the assumptions of capitalism, aiming to maintain the status quo based on dominance and exploitation. Critical Management Studies would like to expose the truth, which leads to questioning of the seemingly 'objective' and 'natural' status of the organisational order, managerial power, institutions, and managerial practices and identity (Alvesson \& Willmott 2003). This 'denaturalisation' of the discourse of managerialism results in the description of activities and institutions based on dominance, which are oppressive and frequently harmful to people and society. However, they remain concealed under the pretence of the rationality of management sciences. The demand to discover the interests of different social groups wielding power - also by controlling scientific discourse - is supposed to lead to criticism and change of an existing, unjust social order. As a result of the development of CMS, disadvantaged groups, being objects of power, such as ethnic and social minorities and women, should build their awareness and gain the possibility to express and further their interests (Grey \& Wilmott, 2005). Their emancipation would be accompanied by discovery of the mechanisms behind symbolic violence, demystification of the managerialism ideology, and a departure from irresponsible and instrumental managerial practices. The tools developed by CMS include: deconstruction and denaturalisation of the managerial discourse, critical and reflective 
analyses of the language of power-wielding, as well as methods for reinforcing the autonomy and self-control of disadvantaged groups (e.g. empowerment, parity), (Parker, 2002).

As a science, management functions within a specific institutional framework, which includes a hierarchy of power and authority. Over the last few decades, academic institutions that deal with this discipline have been promoting models of flexible organisation that is nonhierarchical and open to change. At the same time, they frequently maintain their fossilised, centralised structures. On the level of academic institutions, symbolic power is wielded, which means the development of 'scientificity' standards, research programmes, and curricula. This power, based on the assumptions of CMS, should be carefully watched. Conditions for the creation of valuable, uncensored, and non-monopolised science should then be created (Bourdieu, 1990).

Theory is affected by economic and political power. In today's world, knowledge has lost its previous 'innocence'; it is no longer a 'selfless striving for the truth', but a tool in the hands of political and economic decision-makers. This also concerns management, which was even originally supposed to be used to create the conditions for increasing effectiveness inside organisations. These kinds of organisations are usually business enterprises, but also noncommercial organisations, including oppressive ones, such as the army or police.

Within CMS, management is perceived as a social science, the purpose of which is to manipulate an organisation's members, and so the theory developed accepts externally imposed ideological functions as the objective truths and foundations of this science (Chomsky, 1993). The theory of scientific management rationalised the instrumental and alienating treatment of workers of industrial organisations (Clegg, 1981; Goldman \& Van Houten, 1977). For example, so-called modern management methods, such as re-engineering, lean management and job sharing, have become euphemisms for layoffs. Management methods such as TQM or re-engineering can be used to rationalise organisational power and the managerial discourse, by reproducing ideologies and promoting false awareness among employees (Lawrence \& Philips, 1998). Contemporary management theoreticians sanction the usefulness and inevitability of globalisation processes, but avoid giving answers to troublesome questions about whose interests globalisation serves, and how those who use it support the development of its theory (Thomas, 1979).

Management is a normative science, which should establish principles of effective organisation, serve an auxiliary function to economic practice, and have some practical application. This does happen in some cases, however, without hypocrisy it has to be admitted that application of the theory of effective management is not standard. Businessmen, entrepreneurs and managers frequently don't need any education in management. However, setting a discipline within practice is its basic assumption, which is why academic circles connected with management continue to try to prove the value of applying their theories. So far, however, they have not been very effective in dealing with practice. Consulting activity (advisory services to entrepreneurs and managers), has popped up between academic centres and economic sectors. Consultants make their living by applying theoretical concepts of management, so, under the pretence of having a scientific character, and using the technique of the marketing of ideas, consultancy consolidates the influence and popularity of the management sciences (which does not always translate into their cognitive authority). On the other hand, consulting is the most important form of putting research results into managerial practice. This means establishing a link between theory and practice, which is of key significance in the practical sciences. A description of organisational reality and demands from researchers and specialists presented to managerial practice, can also draw on ideological motivations or attempts to force through the interests of a reference group (Fox, 1974). 
In the $20^{\text {th }}$ century, management sciences became an influential discipline, closely linked to business and power circles. In the institutional sphere of management sciences, various interest groups have formed, which foster their own influences, thus shaping management sciences overall. The most important interest groups include scientists specialising in management, business consultants and advisers, businessmen, entrepreneurs and owners. The stakes in this social game, whose playing field includes the management sciences, are money, social prestige and power. One could also indicate other social divisions, such as managers in the private sector and managers in the public sector, or national divisions of workers, as well as other forms of motivators, such as the sense of security. The interests of these groups overlap to form a complex constellation of more-or-less permanent coalitions that interact in a conscious or subconscious manner. However, the veil of objectivity can hide the interests of social groups involved in this social game.

Today, managers form one of the most influential social groups. They control the flow of funds, goods and services on a global scale. They exercise power in most social structures, over small and large groups of people, frequently even over-riding political decision-makers. According to many representatives of CMS, managerialism in a contemporary capitalist formation has taken control of even the public sector (Fourier \& Grey, 2000). As a dominant group, managers create their own ideology, which allows them to consolidate power and rationalise their position. The managerialism ideology contributes to the creation of group identity and solidarity. It is reflected in object concepts and management methods developed within the dominant current (Alvesson \& Willmott, 1996).

Management sciences are founded on the perspective of instrumental rationalism. Managerial processes aim for effective, efficient work organisation based on scientific (objective and universal) principles. Management sciences have cognitive goals that translate into the pragmatics of managerial actions. The roles of directors, managers and administrators are thus the basic objects of interest of management sciences. An idealised image of their actions is thus created. Description of the decision-making processes in an organisation is based on individualist assumptions of homo oeconomicus, which ignore the key influence of social groups.

The issue of management as an ideology that rationalises the wielding of power runs throughout CMS. The social self of a manager is constructed in accordance with these concepts, and emphasises the rationality of action, pragmatism and utilitarianism, striving for power and success, loyalty to one's organisation, and faith in the managerial ethos. CMS aims to demystify these elements of the manager's identity, indicating that they are only justifications for striving for dominance over others (Parker, 2002).

Power exercised by managers and property owners creates a self-reproducing social order. Maintaining it over a long period requires the use of symbolic violence (Lane, 2000). People subjected to dominance must somehow collectively accept the institutions of ownership, market, and managerialism. According to representatives of CMS, this is ensured by the system rationalising a social dominance - management - that takes the institutionalised form of a social science and practice. N. Harding notes that creators, continuators and promoters of management have developed an extensive system of social legitimisation of power, encompassing business schools, the business publishing market, academic circles, and the lobbying groups centred around management. This mechanism of symbolic violence is used to instil seemingly unquestionable assumptions and content in the social discourse, that maintain reproduction and legitimise power. These assumptions are that:

- Without management, the world would be thrown into chaos;

- Management is a science offering objective truth about external reality; 
- Management is an art that allows the wielding of power over other people (Harding, 2003).

Elaborating on the issue of the ideological character of management, one can also elaborate on the issue of false awareness created by an education system that copies the ideological knowledge of management (Hatch, 2002). According to the representatives of Critical Management Education, business schools 'enslave the minds' of managers and employees, providing them with sources of identity (Willmott, 1997). Identifying oneself with a seemingly scientific, objective, effective and just system that is - according to management eulogists - only possible in today's world system of wielding power, results in false consciousness. According to CMS concepts, false consciousness is produced by the system for the benefit of the dominant social group. It is a tool of control and 'symbolic violence'. Great numbers of people devote their time to absurd pursuits of new things and services, thus driving the development of transnational corporations, owners and top managers, meaning all those at the top of the pyramid (Sułkowski, 2006). False consciousness does not only affect managers, giving them an unjustified sense of mission and justice with regard to the exercising of power in the interest of the organisation, but also employers and consumers who give in to this power through symbolic violence, or as S. Deetz called it, "colonisation of everyday life by concerns" (Deetz, 1995). A significant aspect of power reproduction is managerial education, which is ideological and indoctrinating (Giroux, 1997). It is based on the socialisation of a social group that rationalises the process of wielding power (Grey, 2004).

\section{Methodological approach}

The research methodology is based on a systematic, qualitative review of the literature in two fields: BS in social sciences, and Critical Management Studies (Fisch \& Block, 2018). The aim of the review was to develop a concept of 'BSM'. The basic sources for the literature review included bibliographical data from the following databases: Google Scholar, JSTOR, Scopus, and Web of Science. Additionally, a bibliographical analysis of the terms 'bullshit management' and 'bullshit' was carried out using Google databases.

\section{Conducting research and results}

The phrase 'bullshit management' is not very popular in the management discourse. As of October 31, 2018, only fifteen bibliographical entries containing the phrase could be found in the Google Scholar database, and only four of them are in English. When entering 'bullshit management' in Google, one gets more than 18,900 search results, which indicates that the issue of BSM is completely new to our discourse. However, this could also suggest that compared to representatives of some other social sciences, researchers of organisations and management are more sensitive to the colloquial connotations of the word 'bullshit'. The Google Scholar database offers 61,400 entries containing the term 'bullshit', and an impressive 93,500,500 search results across all of Google (as accessed on October 31, 2018). This seems to prove the poor reception of the idea of BS in the discourse of management sciences.

Today, 'bullshitting' in management is one of the ways of 'producing theory' and 'developing practice' in management. Incoherent and manipulative concepts appear in different areas of management, and as such are sometimes called BS. Examples of these areas include business (Spicer, 2017), accounting (Macintosh, 2006), the globalisation discourse 
(Rosenberg, 2007), self-presentation (Levin \& Zickar, 2002), marketing, education (Holbrook, 2005; Selwyn, 2016; Gaztambide-Fernández, 2011), corporate language (Beckwith, 2006), and many more. BS undoubtedly constitutes the concepts of many 'management gurus', promoted through their consultancy work and by offering the 'philosopher's stone' of business, the frequent purpose of which is flattering the managers' egos (Clark, Bhatanacharoen \& Greatbatch, 2015; Clark \& Salaman, 1998; Barabba, Pourdehnad \& Ackoff, 2002). Also, there is a lot of humbug in the mythologisation of leadership and managerial education, using grandiosity concepts (Alvesson \& Gabriel, 2016). Many concepts that used to occupy the space of 'management fads' have latterly been critically assessed as BS. Here, we could mention just a few - Business Process Reengineering, Organisational Behaviour, Downsizing, Personal Branding (Lair, Sullivan \& Cheney, 2005; Willmott \& Wray-Bliss, 2016; Collins, 2013).

Several areas of the management discourse include texts and organisational practices that could be classified as contained BS, but this does not mean that the cognitive or practical value of the whole current is called into question. Good examples of BSM in this case are connected to the: knowledge management (Despres \& Chauvel, 1999; Grant, 2011), organisational culture (Willmott, 1993), project management (Cicmil, Lindgren \& Packendorff, 2016), marketing (Svensson, 2018; Mason, Kjellberg \& Hagberg, 2015), TQM (Newell, Robertson \& Swan, 2001), and strategic management (Smircich \& Stubbart, 1985).

BSM can draw on CMS theory by drawing on the definition of BSM as "regular and instrumental manipulation of recipients using communication and social actions". But BSM should be exposed both within the theoretical discourse and in managerial practice. This is part of the revealing of 'false consciousness' and 'symbolic violence' that conceal the structures of power (Waring, 1998). The concept of ,symbolic violence' growing from P. Bourdieu is rich in sociological and politological discourse, but very limitied in management and organization theory. Contemporary BSM narratives are also used to maintain power under the pretence of improving security (Lorenz, 2012). Many pompous 'theories and methods of effective management' come down to over-interpretation of social reality, which has no foundation in research. Thus, it is necessary to seek and identify the cognitive and practical weaknesses of managerial and organisational discourses. Demystification of BSM and the managerial discourse can also lead to the development of different forms of resistance against the implementation of dehumanised organisational practices (Ezzamel, Willmott \& Worthington, 2001).

At the same time, CMS researchers should avoid BS. It is no coincidence that according to some researchers, neo-Marxism and the anti-neoliberal discourse both sometimes overstep the boundaries of BS (Cohen, 2002; Dawkins, 1998; Sokal \& Bricmont, 1998). Ways of resistance against managerial BS are: demistification and resistance that could be described as ,weapons of the weak“ (Scott, 2008).

\section{Conclusion}

It seems practically and cognitively valuable to look for manifestations of BS, or even extended forms of BSM, in the discourse of management. Sources of the expansion of BSM include attempts to comment on every issue, attempts to dominate the discourse, repeating the same 'fashionable' concepts, and lack of criticism in the scientific discourse. CMS can provide a warning about falling into BSM, and a source of methods for demystifying and denaturalising activities based on BSM, on the condition that CMS researchers do not ideologise assumptions about the dominance of power over discourse.

BSM discourse shoudn't be treated as universalistic concept. It is contextual, ad what is BSM depends on the cultural background. However the expansion of american and western 
europe patterns in managemen,t manifeted f.ex. by expansion of MBA education, put the dominant critical perspective on american and western Europe concepts of organization and management.

The concept of BSM can play the role of a kind of Occam's razor in management, which might lead to 'cutting out' many overblown, intellectually empty management theories and techniques. Perhaps this will also give rise to a more critical view of the achievements of our science and practice.

The range of BSM is obviously not limitied to free-market or capitalist economies. Different ranges of central planned, socialist and quasi-communist economies has been deeply involved in ideological and deeply misleading versions of BSM. Limitations of the critics and free speech in socialist and communist countries cause the fast development of BSM discourses nd practices.

The concept of BSM can also be accused of methodological weakness, due to a lack of boundaries between synonyms and a lack of a clear definition of empirical measures. It seems, however, that we are at the first stage of a discussion that requires an answer to the question of whether it is worth further developing the issue of BSM. Arguments in favour of raising the issue are the crudeness and social recognisability of BS. Arguments against going further in this direction are the overly emotional language and lack of fully distinct theoretical and methodological frameworks. The problem with BS is similar to the problems with other notions taken from colloquial language and philosophy. They are socially influential, yet very broad. This is why it remains to be seen whether BSM will become an object of research or only a one-off intellectual provocation.

\section{References}

Alvesson, M., \& Gabriel, Y. (2016). Grandiosity in Contemporary Management and Education. Management Learning, 47(4), 464-473. doi: 10.1177/1350507615618321.

Alvesson, M., \& Willmott, H. (1992). Critical Management Studies. Series: SAGE Library in Business and Management. London: SAGE Publications Ltd.

Alvesson, M., \& Willmott, H. (1996). Making Sense of Management. A Critical Introduction. London: SAGE Publications Inc.

Alvesson, M., \& Willmott, H. (2003). Studying Management Critically. London: SAGE Publications Ltd. doi: 10.4135/9781446220030.

Ball, J. (2017). Post-Truth How Bullshit Conquered the World. Biteback Publishing.

Barabba, V., Pourdehnad, J., \& Ackoff, R.L. (2002). On Misdirecting Management. Strategy \& Leadership, 30(5), 5-9. doi: 10.1108/10878570210442498.

Beckwith, L. (2006). The Dictionary of Corporate Bullshit: An A to Z Lexicon of Empty, Enraging, and Just Plain Stupid Office Talk. Wielka Brytania: Kultur International Films.

Belfiore, E. (2009). On Bullshit in Cultural Policy Practice and Research: Notes from the British Case. International Journal of Cultural Policy, 15(3), 343-359. doi: 10.1080/10286630902806080.

Black, M. (1982). The Prevalence of Humbug. Philosophic Exchange, 13(1), 1-25.

Bourdieu, P. (1990). Animaadversiones in Mertonem. In J. Clark, C. Modgil \& S. Modgil (Eds.), Robert K. Merton: Consensus and Controversy, London-New York: The Falmer Press, p. 300.

Braverman, H. (1974). Labor and Monopoly Capital: The Degradation of Work in the Twentieth Century. New York: Monthly Review Press.

Chomsky, N. (1993). Language \& Thought (Anshen Transdisciplinary Lectureships in Art, Science and the Philosophy of Culture). London: Mayer Bell, p. 40. 
Cicmil, S., Lindgren, M., \& Packendorff, J. (2016). The project (management) discourse and its consequences: on vulnerability and unsustainability in project-based work. New Technology, Work and Employment, 31(1), 58-76. doi: 10.1111/ntwe.12058.

Clark, T., \& Salaman, G. (1998). Telling Tales: Management Gurus' Narratives and the Construction of Managerial Identity. Journal of Management Studies, 35(2), 137-161. doi: 10.1111/1467-6486.00088.

Clark, T., Bhatanacharoen, P., \& Greatbatch, D. (2015). Conveying the Adaptation of Management Panaceas: the Case of Management Gurus. In A. Ortenblad (Eds.), Handbook of research on management ideas and panaceas : adaptation and context. Cheltenham: Edward Elgar, 223-242. doi: 10.4337/9781783475605.00028.

Clegg, S. (1981). Organisation and Control. Administrative Science Quarterly, 26(4), 545562. doi: $10.2307 / 2392339$.

Cohen, G.A. (2002). Deeper into Bullshit. In S. Buss \& L. Overton, (Eds.), Contours of Agency: Essays on Themes from Harry Frankfurt. London: The MIT Press, 321-339.

Collins, D. (2013). Management Fads and Buzzwords: Critical-Practical Perspectives. Londyn-New York: Routledge.

Dawkins, R. (1998), Postmodernism Disrobed. Nature, 394, 141-143, https://physics.nyu.edu/sokal/dawkins.html.

Deetz, S. (1995). Transforming Communication, Transforming Business: Building Responsive and Responsible Workplaces. New York: Hampton Press.

Despres, C., \& Chauvel, D. (1999). Knowledge Management(s). Journal of knowledge Management, 3(2), 110-123. doi: 10.1108/13673279910275567.

Eubanks, P., \& Schaeffer, J. D. (2008). A Kind Word for Bullshit: The Problem of Academic Writing. College Composition and Communication, 59(3), 372-388.

Ezzamel, M., Willmott, H., \& Worthington, F. (2001). Power, Control and Resistance in 'the Factory that Time Forgot. Journal of Management Studies, 38(8), 1053-1079. doi: 10.1111/1467-6486.00272.

Fisch, Ch., \& Block, J. (2018). Six tips for your (systematic) literature review in business and management research, 68(2), Springer International Publishing AG. doi: 10.1007/s11301-018-0142-x.

Fourier, V., \& Grey, Ch. (2000). At the Critical Moment: Conditions and Prospects for Critical Management Studies. Human Relations, 53(1), p. 10. doi: 10.1177/0018726700531002.

Fox, A. (1974). Beyond Contract: Work, Power and Trust Relations. London: Faber and Faber.

Frankfurt, H.G. (2005). On Bullshit. Princeton: Princeton University Press, 2-7.

Gaztambide-Fernández, R. (2011). Bullshit as Resistance: Justifying Unearned Privilege Among Students at an Elite Boarding School. International Journal of Qualitative Studies in Education, 24(5), 581-586. doi: 10.1080/09518398.2011.600272.

Giroux, H.A. (1997). Pedagogy and the Politics of Hope: Theory, Culture, and Schooling, A Critical Reader. Boulder, CO: Westview Press.

Goldman, P., \& Van Houten, D.R. (1977). Managerial Strategies and the Worker: A Marxist Analysis of Bureaucracy. The Sociological Quarterly, 18(1), 108-125.

Grant, K. (2011). Knowledge management: an enduring but confusing fashion. The Electronic Journal of Knowledge Management, 9(2), 117-131.

Grey, C. (2004). Reinventing business schools: The contribution of critical management Education. Academy of Management Learning and Education, 3(2), 178-186.

Grey, C., \& Wilmott, H.C. (2005). Critical Management Studies: A Reader. Oksford, Wielka Brytania: Oxford University Press.

Harding, N. (2003). The Social Construction of Management. London: Routledge, p. 14. 
Hatch, M.J. (2002). Teoria organizacji. Warszawa: PWN, p. 337.

Holbrook, M.B. (2005). Marketing Miseducation and the MBA Mind: Bullshit Happens. Marketing Education Review, 15(3), 1-5. doi: 10.1080/10528008.2005.11488915. https://dictionary.cambridge.org/dictionary/english/bullshit, 31.10.2018.

Lair, D.J., Sullivan, K., \& Cheney, G. (2005). Marketization and the Recasting of the Professional Self: The Rhetoric and Ethics of Personal Branding. Management Learning, 18(3), 307-343. doi: 10.1177/0893318904270744.

Lane, J.F. (2000). Pierre Bourdieu: A Critical Introduction (Modern European Thinkers). Londyn: Pluto Press.

Lawrence, T.B., \& Philips, N. (1998). Commentary: Separating Play and Critique: Postmodern and Critical Perspectives on TQM/BPR. Journal of Management Inquiry, 7(2), 154-160. doi: 10.1177/105649269872010.

Lenart-Gansiniec, R., \& Sułkowski, Ł. (2018). Crowdsourcing - A New Paradigm of Organizational Learning of Public Organizations. Sustainability, 10(10), 3359. doi:10.3390/su10103359.

Levin, R.A., \& Zickar, M.J. (2002). Investigating Self-Presentation, Lies, and Bullshit: Understanding Faking and its Effects on Selection Decisions Using Theory, Field Research, and Simulation. In J.M. Brett \& F. Drasgow (Eds.), The Psychology of Work: Theoretically Based Empirical Research, Mahwah, NJ, US: Lawrence Erlbaum Associates Publishers, 253-276.

Lorenz, C. (2012). If You're so Smart, Why Are You Under Surveillance? Universities, Neoliberalism, and New Public Management. Critical inquiry, 38(3), 599-629. doi: $10.1086 / 664553$.

Macintosh, N.B. (2006). COMMENTARY - Accounting - Truth, Lies, or 'Bullshit'? A Philosophical Investigation. Accounting and the Public Interest, 6(1), 22-36. doi: 10.2308/api.2006.6.1.22.

Mason, K., Kjellberg, H., \& Hagberg, J. (2015). Exploring the Performativity of Marketing: Theories, Practices and Devices. Journal of Marketing Management, 31(1-2), 1-15. doi: 10.1080/0267257X.2014.982932.

Newell, S., Robertson, M., \& Swan, J. (2001). Management Fads and Fashions. Organization, 8(1), 5-15. doi: 10.1177/135050840181001.

Parker, M. (2002). Against Management: Organisation in the Age of Managerialism. Oxford, Wielka Brytania: Polity.

Pennycook, G., \& Rand, D.G. (2018). Who falls for fake news? The roles of bullshit receptivity, overclaiming, familiarity, and analytic thinking. https://www.researchgate.net/publication/321887938, 31.10.2018.

Rosenberg, J. (2007). International Relations - the 'Higher Bullshit': a Reply to the Globalisation Theory Debate. International Politics, 44(4), 450-482. doi: 10.1057/palgrave.ip.8800200.

Scott, J. C. (2008). Weapons of the weak: Everyday forms of peasant resistance. Yale University Press.

Selwyn, N. (2016). Minding our language: why education and technology is full of bullshit ... and what might be done about it. Learning, Media and Technology, 41(3), 437-443. doi: 10.1080/17439884.2015.1012523.

Sismondo, S. (2018). Extraordinary Popular Delusions and the Manipulation of Crowds. In C.G. Prado (Eds.), America's Post-Truth Phenomenon: When Feelings and Opinions Trump Facts and Evidence, 72, Santa Barbara: ABC-CLIO.

Smagorinsky, P., Daigle, E.A., O’Donnell-Allen, C., \& Bynum, S. (2010). Bullshit in Academic Writing: A Protocol Analysis of a High School Senior's Process of 
Interpreting Much Ado About Nothing. Research in the Teaching of English, 44(4), 368-405.

Smircich, L., \& Stubbart, C. (1985). Strategic Management in an Enacted World. Journal of Management Review, 10(4), 724-736. doi: 10.2307/258041.

Sokal, A. D. (1996). Transgressing the Boundaries: Toward a Transformative Hermeneutics of Quantum Gravity. Social Text, 46/47, 217-252.

Sokal, A.D., \& Bricmont, J. (1998). Intellectual Impostures: Postmodern Philosophers' Abuse of Science. Londyn, Wielka Brytania: Profile Books Ltd.

Spicer, A. (2017). Business Bullshit. Londyn: Routledge.

Sułkowski, Ł. (2006). Społeczeństwo informacyjne a kultura konsumpcyjna. In A. Binsztok (Eds.), Koncepcje, modele $i$ metody zarzadzania informacja $i$ wiedza. Wrocław: Wydawnictwo Akademii Ekonomicznej.

Sułkowski, Ł. (2010). Two Paradigms in Management Epistemology. Journal of Intercultural Management, 2(1), 109-119.

Sułkowski, Ł. (2013). Epistemology of Management. Szwajcaria: Peter Lang.

Svensson, P. (2018). Critical Studies of Marketing Work. In M. Tadajewski, M. Higgins , J. Denegri-Knott \& R. Varman (Eds.), The Routledge Companion to Critical Marketing. Routledge Taylor \& Francis Group, 171-187.

Thomas, S. (1979). The Multi-National Companies. Hove: Wayland Publishers.

Waring, P. (1998). The Paradox of Prerogative in Participative Organisations: The Manipulation of Corporate Culture?. Current Research in Industrial Relations, Proceedings of the 12th AIRAANZ Conference, Wellington.

Willmott, H. (1993). Strength Is Ignorance; Slavery Is Freedom: Managing Culture in Modern Organisations. Journal of Management Studies, 30(4), 515-552. doi: 10.1111/j.14676486.1993.tb00315.x.

Willmott, H. (1997). Critical Action Learning. In J. Burgoyne, \& M. Reynolds (Eds.), Management Learning: Integrating Perspectives in Theory and Practice, London: Sage, 161-176.

Willmott, H., \& Wray-Bliss, E. (2016). Process Reengineering, Information Technology and the Transformation of Accountability: The Remaindering. In W.J. Orlikowski, G. Walsham, M.R. Jones \& J.I. Degross (Eds.), Information Technology and Changes in Organizational Work, p. 62. doi: 10.1007/978-0-387-34872-8_6. 